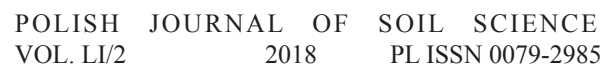

DOI: $10.17951 / \mathrm{pjss} / 2018.51 .2 .229$

KAROLINA HERODOWICZ*, JAN PIEKARCZYK*

\title{
EFFECTS OF SOIL SURFACE ROUGHNESS ON SOIL PROCESSES AND REMOTE SENSING DATA INTERPRETATION AND ITS MEASURING TECHNIQUES - A REVIEW
}

Received: 10.04 .2018

Accepted: 13.07.2018

Abstract. Surface roughness is a very important physical feature of soil, affecting various soil processes and accuracy of remote sensing data interpretation. Thus, there is a need to describe it quantitatively. The main aim of the paper was to show needs and benefits of collecting quantitative information about soil surface roughness which is the most relevant parameter used as an index to predict water and wind erosion. Surface roughness can reduce soil erosion and soil losses even by up to $31 \%$. Thereby, it increases the development of fauna and flora and improves the structure of soil and its biological quality. In the first section of the paper there are presented definitions of soil roughness proposed by different authors. The next section explains how various factors influence soil surface roughness. Then, the categorization of soil surface roughness discussed in literature is presented. The next part of the paper includes information about a role of soil roughness in agricultural, soil science and a hydrology research. Moreover, soil surface roughness plays an important role in a remote sensing of soils. The knowledge of quantitative soil surface roughness allows more accurate interpretation of the soil properties from remote sensing data, because this soil feature can decrease soil spectra even over $70 \%$ and makes their analysis difficult. In addition, deepening knowledge about soil roughness will allow more precise conclusions about the amount of reflected shortwave solar radiation indirectly shaping the Earth's climate. In the final section, the techniques for measuring and indices for describing soil roughness are shown. However, the authors prefer a photogrammetry technique for collecting these data, because it is quick and easy

* Adam Mickiewicz University in Poznań, Department of Soils Science and Remote Sensing of Soils, Poznań, Krygowskiego 10, 60-101, Poland; corresponding author: e-mail: karolina. herodowicz@amu.edu.pl. 
to use, ensuring high resolution and accuracy of data (about $1 \mathrm{~mm}$ ) and the image processing is currently simplified as software to process is absolutely affordable.

Keywords: soil surface roughness, tillage treatments, soil processes, remote sensing, soil surface roughness measuring techniques

\section{INTRODUCTION}

The land areas on the Earth are occupied by agriculture in about 38\% (FAO 2011) and they are the largest land use areas on the planet (Ramankutty et al. 2008). Furthermore, these areas are still growing, but most dynamically in the tropics (Foley et al. 2011). These lands are the best suited for farming in terms of terrain, weather and soil conditions (Ramankutty et al. 2002). On the whole, the agriculture is an important part of economy in the world, but also is a dominant force creating many environmental threats such as climate change $\left(\mathrm{CO}_{2}\right.$ and other greenhouse gas emission increase), biodiversity loss, water and soil degradation (Foley et al. 2005, Power 2010, Foley et al. 2011). Thus, alternative agricultural activities are taken in order to increase production, however, without further environmental degradation. The sustainable land management practices are necessary for humanity in terms of food security and environmental protection (Zheng et al. 2014). The agricultural activity is integrally related with the cultivation of soil, the main purpose of which is to form appropriate physical conditions for crop growth, development and a whole production. This is achieved through creation of a desired soil surface shape which is optimal for planting, irrigation and harvesting operation (Korucu et al. 2016). Tillage practices, which directly impact on soil and water quality, are variable in space and time and depend on the expected soil surface shape. Also specific economic and environmental situation of a farm (agricultural region) affects a selection of a cultivation tool (Daughtry et al. 2006). Thus, the costs of these treatments depend on the kind of the cropping practices and soil conditions on the specific areas. However, the same tillage practice can produce various soil conditions depending on the soil type and weather conditions and can create even such soil conditions that were not intended (Currence 1969).

Since tillage is a very important element of crop production and may have the greatest impact on the environment (Lobb et al. 2007) there is a need to evaluate the quality of conducted tillage treatments. Soils tillage is strongly related to soil surface roughness (García Moreno et al. 2011) defined as irregularities occurring on the soil surface (Thomsen et al. 2015). Therefore, soil surface roughness can be used as a measure of the effectiveness of tillage practices (Currence 1969). Monitoring of soil surface roughness is important, because it plays a key role as an input parameter for many soil erosion models (Gilliot et al. 2017) such as the Sealing and Transfer by Runoff and Erosion (STREAM) 
(Cerdan et al. 2002) or the Universal Soil Loss Equation (USLE) (Wischmeier and Smith 1978). Models for prediction of water storage and infiltration (Moldenhauer 1970) or for prediction of an albedo (Matthias et al. 2000) were also created. The soil surface roughness parameter is used for a crop simulation in the model Crop Environment Resource Synthesis (CERES) (Jones and Kiniry 1986). The Volt'Air model is for prediction of gas emissions caused by agricultural treatments (Génermont and Cellier 1997). Besides, soil surface roughness influences the predicting accuracy of soil properties using visible (Vis) and near-infrared reflectance (NIRS) methods (Viscarra Rossel et al. 2006, Vaudour et al. 2013), their reflectance spectra (Cierniewski and Kuśnierek 2010, Piekarczyk et al. 2016, Herodowicz 2017). Moreover, the knowledge about soil roughness allows distinguishing cultivated and uncultivated bare surfaces using remote sensing techniques (Cierniewski et al. 2004) and deeper understanding of the mechanism of global warming (Cierniewski et al. 2015).

The objective of this paper was to provide a comprehensive review of needs and benefits of monitoring soil surface roughness, resulting from tillage practices. The outlines of the techniques that were previously used and these which are used currently are the state-of-the-art for measuring soil roughness. The advantages and disadvantages of these techniques were discussed. Moreover, the parameters that best describe the soil surface roughness were showed. At the beginning of the paper, background information pertaining to soil surface roughness as well as to the factors influencing soil surface states, and the kinds of soil roughness is provided. There is underlined an important role of soil surface roughness in agriculture, hydrology, transport processes, in reducing erosion and losses of soil and in remote sensing. Then, the different measuring methods of soil surface roughness are reviewed with particular attention to a photogrammetry technique. The authors also showed various coefficients for quantitative description of the soil surface roughness.

\section{SOIL SURFACE ROUGHNESS}

\section{The definitions of soil surface roughness}

Each tillage tool generates a particular type of a soil surface shape under identical soil conditions (in terms of moisture, texture, bulk density, etc.), defined in the three-dimensional space (Korucu et al. 2016) which is called soil surface roughness. Hauer et al. (2001) defined it as a variable feature of soil, which influences many processes occurring at the soil surface, whereas Vidal Vázquez et al. (2005) described it as a micro variation in the surface elevation present on a field surface. Other authors defined it as the standard deviation of neighbouring point elevation measurements (Vannier et al. 2006, García More- 
no et al. 2008a), whereas Thomsen et al. (2015) defined soil surface roughness simply as irregularities on its surface.

\section{The factors affecting soil surface roughness}

Soil surface roughness depends on farming practices (Baghdadi et al. 2008, Cierniewski et al. 2015), climatic factors (Korucu et al. 2016), soil texture (Vidal Vázquez et al. 2005) and soil properties promoting the formation of aggregates of appropriate size and stability on the surface (Duiker et al. 2003). The formation of soil aggregates is particularly strongly affected by the presence of clay, iron oxide, organic carbon, calcium carbonate and moisture in soil (Bronick and Lal 2005, Barthès et al. 2008). Thomsen et al. (2014) added rock fragments and vegetation cover to the above factors forming the soil surface roughness. The precipitation is the factor that causes a progressive decrease in the soil surface roughness (Cierniewski 1999, Vermang et al. 2013). However, if rill erosion processes are dominant in the field after rainfall, soil surface roughness can increase (Vidal Vázquez et al. 2007). Roughness increase at rainfall was also observed by Huang and Bradford (1992) but this concerned soil surfaces with small roughness state. According to Rosa et al. (2012), an increase of the soil surface roughness can also occur, when after rain the large soil aggregates and clods disintegrate into smaller ones.

\section{The categorization of soil surface roughness}

Considering the variability of soil surface roughness in terms of the order of elevation magnitude variations and the spatial arrangement of surface peaks and depressions, various roughness categories can be distinguished. A very simple division into two categories, oriented and random roughness, was proposed by Allmaras et al. (1966). The former category includes an effect of the cultivation tools on the soil surface, whereas the latter depends on the presence of aggregates and clods on the soil surface, which form randomly distributed elevations and depressions. Later, Römkens and Wang (1986) categorized soil surface roughness into four groups and then, Martinez-Agirre et al. (2016) stated that these categories are still current. The first category is micro-relief variations determined by individual soil grains and very small aggregates, while the second category is a random roughness related to clods. The third category is oriented roughness characterized by systematic elevation variations in the topography due to e.g. tillage, if concentrated erosion occurs and gullies which also create random roughness. The last category of soil surface roughness is higher-order, representing elevation variations in the larger-scale (field or basin scale) roughness. Abban et al. (2017) following Oades and Waters (1991) proposed roughness classification taking into account the length scale. In the first group are individual soil grains and aggregates forming soil roughness from 
0.053 to $2.0 \mathrm{~mm}$. The next group consists of variations of soil clods on the order of 2-100 $\mathrm{mm}$. The last group includes the soil roughness created by tillage ranging between 100 and $300 \mathrm{~mm}$. However, various kinds of soil surface roughness may be superimposed onto each other and may appear together on fields (Kamphorst et al. 2000, Vidal Vázquez et al. 2005).

\section{Influence of soil surface roughness on soil processes}

Soil surface roughness plays a key role in agriculture, hydrology and transport processes but also in remote sensing. Soil roughness determines the intensity of water and wind erosion (Vidal Vázquez et al. 2005) thus, is the most relevant parameter used as an index to predict these processes (García Moreno et al. 2008b) because it can be employed to define the potential for soil particle saltation, emission and retention (Potter et al. 1990).

Soil surface roughness determines the heat exchange and the development of fauna and flora that can function in a particular ecosystem. Microbial activity is necessary for most biogeochemical cycles and support the development of all other living organisms (Or et al. 2007). Soil surface roughness indirectly affects the soil surface temperature (Cruse et al. 1980) and the moisture and air content in the soil (Vidal Vázquez et al. 2005), thus, consequently it can influence an abundance and diversity of soil biota. Increasing soil surface roughness improves the structure of soil and its biological quality (Young et al. 2001). However, Röhrig et al. (1998) noted that for the development of soil mesofauna (e.g. Enchytraeidae), the most favourable conditions occur when the soil is not strongly disturbed.

\section{Water erosion}

Water retention, a flow concentration and flow networking indexes can be estimated on the basis of soil surface roughness (Vidal Vázquez et al. 2006). Soil surface roughness can dominate the mechanism of overland water flow, its intensity and speed of the flow surface (Kamphorst et al. 2000), water infiltration (Magunda et al. 1997, Amoah et al. 2013), the quantity of stored water in the soil (Vidal Vázquez et al. 2005) and, ultimately, sediment detachment (Amoah et al. 2013). According to Darboux et al. (2002), intensity of surface runoff depends on its scale and on a small scale, below $10 \mathrm{~cm}$, it causes slower flow of water on the soil surface.

\section{Wind erosion}

In semi-arid regions, wind erosion dominate, which provides the loss of organic matter and nutrient (Larney et al. 1999). Therefore, proper use of tillage treatments, which create soil surface roughness, can decrease wind erosion 
(Larney et al. 1995, Murillo et al. 2004). Research conducted by Fryrear (1984) and Arika et al. (1986) confirmed that if soil roughness is higher, the erosion is lower.

\section{Soil surface roughness created by tillage treatments reducing erosion and soil losses}

The severity of soil erosion can be reduced by the proper use of tillage practices which affect aggregate size distribution and soil surface roughness (Larney et al. 1995, Murillo et al. 2004). Ghidey and Alberts (1998) conducted research of rainfall erosion on 28 soil surfaces. They observed that the annual surface runoff was decreased by $5 \%$ on a silt loam soil cultivated by chisel plowing that increases soil surface roughness in comparison to conventional practices which create lower soil surface roughness. Thereby, soil losses caused by leaching were lowered by $31 \%$. Soil surface roughness created by tillage practices in addition to reduction of soil erosion also decreases the amount of the loss of organic matter and nutrients in a soil. Ginting et al. (1998) noted higher phosphorus losses on the fine-loamy soil after mouldboard plough (forming lower soil surface roughness). It was due to higher runoff and sediment losses in comparison to ridge tillage, which creates higher soil surface roughness.

\section{Soil surface roughness in remote sensing}

Soil surface roughness resulting from the presence of soil particles and aggregates is one of the important factors determining its spectral properties (Richter et al. 2009). Sometimes the effect of roughness on the spectral properties of the soil may be greater than the impact of the chemical characteristics of the soil (Ben-Dor et al. 2003). Along with the reduction in the size of soil aggregates, the amount of solar energy reflected from them is greater (Mikhajlova and Orlov 1986). This applies both to the soil surface before and after agro-technical operations (Sullivan et al. 2005). The authors noted that sandy soil surfaces, which tended to be encrusted, before agro-technical treatments reflected more radiation, than after carried out treatments. This is caused by a rainfall or an irrigation, which cause slow separation of small particles of silt and clay from the quartz particles. These small, separated particles move deep into the soil pores, leaving bright particles of quartz on a soil surface. Cierniewski et al. (2013) observed that the same soil freshly ploughed with a very rough surface shows a short-wave reflectance two times lower in comparison to the soil smoothed with shaft. Soil surface roughness created after the precipitation increases the amount of reflected energy by about 25\% (Potter et al. 1987). The amount of reflected solar energy changes with the change in soil surface roughness. Rough soil surfaces are darker because they create self-shadowing and, as a conse- 
quence, the solar radiation does not directly reach the surface. The shaded areas reflect less radiation compared to directly illuminated one (Cierniewski 1999, Matthias et al. 2000). Another reason for the low spectral reflectance from the soil surface with large soil particles is capturing - by particles and aggregates located on this surface - a large part of the energy (Cierniewski 1987).

\section{Usage of remote sensing for analysing the soil surface}

Diffuse and contact reflectance spectroscopy or proximal soil sensing rely on registration of reflected radiation from an analysed surface, usually in the wavelength range of 350-2,500 $\mathrm{nm}$ (Cecillon et al. 2008). This technique is rapid, relatively inexpensive and is an effective method of reliable quantitative assessment of soil properties such as silt, clay, sand, nitrogen, organic matter, moisture or heavy metal contents (Ben-Dor and Banin 1995, Moron and Cozzolino 2003, Brunet et al. 2007). This technique can support a traditional soil physical and chemical analysis. Especially in precision agriculture where a great number of soil samples are needed to describe in detail the variability of the soil in the field scale (Nanni and Demattê 2006). Soil spectral data can be acquired not only under laboratory conditions but also from other remote sensing platforms, satellites, aircraft or ground level. Soil surfaces measured under laboratory conditions differ from in situ field surfaces, primarily in roughness and water content, because samples taken in field and transferred to the laboratory are usually homogenised, e.g. dried, ground and sieved before spectral measurements.

\section{Influence of soil surface roughness on its spectra}

Soil surface roughness strongly affects its reflectance spectra measured under field conditions (Croft et al. 2012, Piekarczyk et al. 2016) and under laboratory conditions (Richter et al. 2005, Piekarczyk et al. 2016, Herodowicz 2017). Homogenised, fine-grained soils have a smoother surface and their brightness is higher compared to coarse-grained soils which have more cavities and gaps, which are trap for incident radiation and reflect less energy over the whole VIS/ NIR range (Mikhajlova and Orlov 1986, Van der Meer 1995, Cierniewski and Kuśnierek 2010, Herodowicz 2017). However, there was noted that on surfaces of soils with higher clay contents, sieved through a $2 \mathrm{~mm}$ and more sieve, can be created small agregatess. These soil surfaces seem darker in comparison with soils with higher sand contens, sieved through the same sieve (Ben-Dor et al. 1999). The soil with the highest roughness state can be darker even over $70 \%$ then the same soil but with minimum roughness state, characterized by diffused reflectance spectra. Such high differences of reflectance were observed for specific soil properies (e.g. for content of sand, silt, clay of $15,70,15 \%$, respectively, SOC contents about $3 \%$ ), as well as for specific zenith position of light 
source $\left(60^{\circ}\right)$ and the zenith position of the sensor which observed soil samples from a distance of $10 \mathrm{~cm}$ (Herodowicz 2017) (Fig. 1). Since roughness strongly affects spectral measurements, information about the soil micro-relief is necessary that its impact can be corrected (Gilliot et al. 2017).

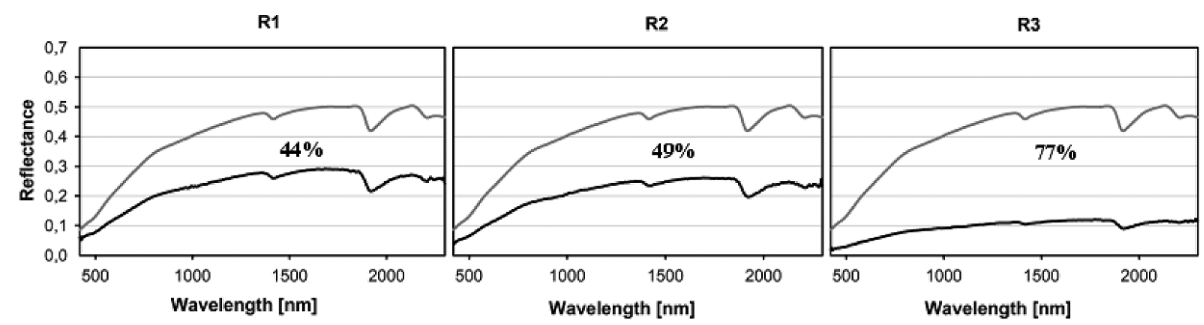

Fig. 1. The reflectance spectra of the dark soil samples in the lowest (R1), the medium (R2) and the highest (R3) surface roughness observed at the sensor height of $10 \mathrm{~cm}$ (black lines) and the reflectance spectrum of the soil sample with minimum roughness state, diffused reflectance spectra (gray lines) illuminated at light source zenith angle equal to $60^{\circ}$ (Herodowicz 2017)

\section{Influence of soil surface roughness on the prediction of soil properties}

Reflectance spectroscopy is used for the analysis of many soil properties (Viscarra Rossel et al. 2006) but it is an indirect technique. The soil inference is due to creating empirical models, which describe relation between spectral data and soil properties (Steinberg et al. 2016), especially based on laboratory spectra (Stevens et al. 2008). However, the research conducted by Piekarczyk et al. (2016) on 20 soil samples with various properties and surface roughness shows that in order to assess soil properties, it is necessary to take into account soil surface roughness. The soil spectra obtained in the VNIR range (400-1,360 $\mathrm{nm})$ and the SWIR range $(1,490-2,300 \mathrm{~nm})$ showed certain patterns. The authors noted that with the increasing soil surface roughness, the level of spectra decreased in relation to soil samples with minimum roughness state, up to $60 \%$. The authors pointed out that developing correction methods or taking into account soil surface roughness will allow the full use of spectra collected for the prediction of soil properties.

Sullivan et al. (2005) noted that the relationship between clay content in soil and image data from IKONOS satellite was similar. The images were recorded before and after agro-technical operations and value of determination coefficients, with clay content in soil, $\mathrm{R}^{2}$ equalled 0.61 and 0.58 , respectively. In the case of the relationship between image data and the carbon content in soil, greater similarity was observed for the soil surface with higher roughness level (after cultivation). The dependences between these soil parameters described above were weaker in the soil with a clay texture and rougher after a treatment than in the sandy soil. The sandy soil after the same treatment is smoother than 
the clay soil. The authors claim that the high roughness of the soil surface is the main factor limiting the accuracy of the estimation of carbon content when its concentration is small $(<1 \%)$.

Scientists make an attempt to predict quantitative soil surface properties for large scales (Grunwald et al. 2011, Arrouays et al. 2014). Huge opportunity to reach this aim is remote sensing, and more specifically, imaging spectroscopy (Ben-Dor et al. 2009, Stevens et al. 2010, Bayer et al. 2012). Therefore, in the near future, there will be available hyperspectral sensor like EnMAP (Environmental Mapping and Analysis Program) from Germany (Guanter et al. 2015) or HISUI (Hyperspectral Imager Suite) from Japan. These instruments could provide data for quantitative assessment of soil properties at large scale, quickly, at low costs and with high accuracy of data. However, alongside many advantages, there also exist some limitations such as the need for manual fine-tuning or occurrence of noises in image caused by moisture, vegetation or soil surface roughness, etc. (Steinberg et al. 2016). They conducted research which aimed at an assessment of potential of the EnMAP sensor for collecting information about quantitative soil surface properties. The sensor was equipped with more than 240 spectral bands and had the spatial resolution of $30 \mathrm{~m}$. The authors pointed to the high potential of this instrument for predicting quantitative surface soil properties. However, they stressed that a soil surface roughness influence the accuracy of prediction and this factor has to be considered. The accuracy and reliability of these data will depend on taking into account an impact of soil surface roughness during pre-processing and interpretation of image data.

Based on aerial or satellite images, estimation of spatial diversity of soil properties for determination of homogeneous zones in a field for precision agriculture, requires the knowledge of soil surface roughness occurring during the images registration. Spatial diversity of soils properties may be presented by means of detailed digital soil maps created by multivariate clustering algorithms such the fuzzy c-means. This method was used for clustering IKONOS images by Sullivan et al. (2005). Clustering carried out with this method on images with the field with a light soil on which surface crusting occurred, gave a different number of clusters depending on whether the surface was smooth (before tillage with crust) or rough (after tillage). In the image acquired before the tillage treatment only two homogeneous soil zones have been delineated, while in the post-tillage image the field surface variation was larger and four such zones were identified.

\section{Influence of soil surface roughness on the shortwave solar radiation}

Soil surface roughness plays a key role in a deeper understanding of the mechanism of global warming which is one of the most important scientific problems. Shortwave solar radiation reflected from the soil surface affects 
the temperature of the soil surface and decides about the climate on the Earth (Cierniewski et al. 2015). However, Iziomon and Mayer (2002) claimed that the precise analysis of the energy balance of the Earth due to the presence of soil surface roughness has been difficult, whereas Cierniewski et al. (2015) noted that the smoother soil reflects more of the radiation and it absorbs heat to a lesser extent as compared to the coarse soils. A deeper understanding of how the soil surface roughness affects the amount of reflected shortwave solar radiation, perhaps in the future, it will allow to influence the amount of reflected shortwave solar radiation by changing the soil surface roughness on a global scale.

Measuring methods of soil surface roughness and parameters describing its state

Adequate methods and instruments should be chosen to quickly measure a state of soil roughness because soil surface roughness, along with its moisture, is the soil feature which is the most variable in time (Bielders et al. 1996) and is susceptible to change due to the action of meteorological factors, e.g. precipitation (Rosa et al. 2012), wind and temperature changes in the low atmosphere (Pardini 2003) or even animal activity. Also spatial variability of roughness, even within small fields, can be high due to the variability of soil properties. Since soil surface roughness is a soil feature highly variable in time and also in space, the most suitable measurement method of soil surface roughness depend on the adopted scale (Zhixiong et al. 2005, Verhoest et al. 2008, Álvarez-Mozos et al. 2011). Acquisition of quantitative data describing soil surface roughness requires high accuracy since sometimes the differences in a field, after specified tillage practices, are very subtle. Measurement instruments used for this purpose should allow the registration of the smallest details of the soil surface (García Moreno et al. 2008a).

There are many tools for collecting these data and they differ from each other with respect to accuracy, resolution, the required size of the measured surface and also in terms of costs or workability in the field (Table 1). Tools for measuring soil surface roughness have accuracy from about $1 \mathrm{~mm}$ (e.g. camera for stereo-photography or laser scanner) to about $1 \mathrm{~cm}$ (pin meter). The researchers claim that for many applications, the soil surface area limited to about $1 \mathrm{~m}^{2}$ should be sufficient (Hansen et al. 1999, Kamphorst et al. 2000, Vidal Vázquez et al. 2006) and the use of only one measurement method within one study is recommended (Thomsen et al. 2015).

Soil surface roughness measurement techniques can be divided into two groups, two dimensional (2D) profile measurements and three dimensional (3D) measurements (Korucu et al. 2016). The second division include contact (invasive) and non-contact (non-invasive) methods (Bretar et al. 2013). In the 2D measurements, contact techniques are used with pin and profile meters or a roller chain. 
Table 1. Summary of measuring methods of soil surface roughness

\begin{tabular}{|c|c|c|c|c|}
\hline $\begin{array}{l}\text { Measuring } \\
\text { methods }\end{array}$ & References & $\begin{array}{l}\text { Contact } \\
\text { method }\end{array}$ & Advantages & Disadvantages \\
\hline $\begin{array}{l}\text { Pin and } \\
\text { profile } \\
\text { metres }\end{array}$ & $\begin{array}{l}\text { Römkens et al. } \\
\text { 1986; Wagner } \\
\text { and Yiming 1991; } \\
\text { García Moreno } \\
\text { 2006; García } \\
\text { Moreno et al. } \\
\text { 2008b; Thomsen } \\
\text { et al. } 2015\end{array}$ & Yes & $\begin{array}{l}\text { Quite a simple tool; easy } \\
\text { workability; inexpensive; } \\
\text { good for comparison of } \\
\text { different roughness states }\end{array}$ & $\begin{array}{l}\text { Destructive effects on } \\
\text { a soil surface; no pos- } \\
\text { sibility of carrying out } \\
\text { measurements on the same } \\
\text { surface; recording equip- } \\
\text { ment is required; it has } \\
\text { limited applicability; it is } \\
\text { time-consuming; impracti- } \\
\text { cal in the field, low spatial } \\
\text { resolution }\end{array}$ \\
\hline $\begin{array}{l}\text { Roller } \\
\text { chain }\end{array}$ & $\begin{array}{l}\text { Saleh 1993; } \\
\text { Skidmore 1997; } \\
\text { Thomsen et al. } \\
2015\end{array}$ & Yes & $\begin{array}{l}\text { Quite a simple tool; inex- } \\
\text { pensive; quite reasonable } \\
\text { results }\end{array}$ & $\begin{array}{l}\text { Destructive effects on } \\
\text { a soil surface; no possibili- } \\
\text { ty of carrying out measure- } \\
\text { ments on the same surface; } \\
\text { has limited applicability; is } \\
\text { time-consuming; impracti- } \\
\text { cal in the field, low spatial } \\
\text { resolution }\end{array}$ \\
\hline $\begin{array}{l}\text { Shadow } \\
\text { analysis }\end{array}$ & $\begin{array}{l}\text { García Moreno et } \\
\text { al. 2008a, } 2011\end{array}$ & No & $\begin{array}{l}\text { Non-destructive effects on } \\
\text { a soil surface; possibility } \\
\text { of carrying out measure- } \\
\text { ments on the same surface } \\
\text { simpler and faster than } \\
\text { in the above-mentioned } \\
\text { methods; inexpensive }\end{array}$ & $\begin{array}{l}\text { Recording equipment is } \\
\text { required; it has limited } \\
\text { applicability; kind of soils } \\
\text { and lighting conditions } \\
\text { have a high impact on the } \\
\text { accuracy of measurement; } \\
\text { low spatial resolution }\end{array}$ \\
\hline $\begin{array}{l}\text { Ste- } \\
\text { reo-pho- } \\
\text { tography }\end{array}$ & $\begin{array}{l}\text { Kamphorst et al. } \\
\text { 2000; Zribi et } \\
\text { al. 2000; Jester } \\
\text { and Klik 2005; } \\
\text { Aguilar et al. } \\
\text { 2009; Nouwak- } \\
\text { po et al. 2010; } \\
\text { Cierniewski et al. } \\
2015\end{array}$ & No & $\begin{array}{l}\text { Non-destructive effects on } \\
\text { a soil surface; possibility } \\
\text { of carrying out meas- } \\
\text { urements on the same } \\
\text { surface; no limits in the } \\
\text { field; high resolution data } \\
\text { and accuracy; fast data } \\
\text { acquisition }\end{array}$ & $\begin{array}{l}\text { Quite expensive equip- } \\
\text { ment; appropriate meas- } \\
\text { urement methodology is } \\
\text { required (e.g. obtained } \\
\text { REA); a measurement } \\
\text { for limited area; worse } \\
\text { results in case of rougher } \\
\text { surface; create DEMs; it is } \\
\text { time-consuming }\end{array}$ \\
\hline $\begin{array}{l}\text { Laser } \\
\text { scanning }\end{array}$ & $\begin{array}{l}\text { Römkens and } \\
\text { Wang 1987; } \\
\text { Flanagan } \text { et al. } \\
\text { 1995; Kamphorst } \\
\text { et al. 2000; Dar- } \\
\text { boux and Huang } \\
\text { 2003; Lichti and } \\
\text { Jamtsho 2006; } \\
\text { Aguilar et al. } \\
\text { 2009: Mirzaei et } \\
\text { al. 2012; Bretar } \\
\text { et al. 2013 }\end{array}$ & No & $\begin{array}{l}\text { Non-destructive effects on } \\
\text { a soil surface; possibility } \\
\text { of carrying out measure- } \\
\text { ments on the same sur- } \\
\text { face; high resolution data } \\
\text { and accuracy; register is } \\
\text { more detailed than in case } \\
\text { of stereo-photography }\end{array}$ & $\begin{array}{l}\text { Quite expensive equip- } \\
\text { ment; create DEMs; it is } \\
\text { time-consuming; difficult } \\
\text { workability; calibration } \\
\text { and configuration device } \\
\text { is required; processing is } \\
\text { time-consuming and an ex- } \\
\text { tensive knowledge and ex- } \\
\text { pert software are required; } \\
\text { limitation is the tendency } \\
\text { for roughness overestima- } \\
\text { tion; worse results in case } \\
\text { of rougher surface }\end{array}$ \\
\hline
\end{tabular}




\begin{tabular}{|c|c|c|c|c|}
\hline $\begin{array}{l}\text { Measuring } \\
\text { methods }\end{array}$ & References & $\begin{array}{l}\text { Contact } \\
\text { method }\end{array}$ & Advantages & Disadvantages \\
\hline Radar & $\begin{array}{l}\text { Santanello et al. } \\
\text { 2007; Loew and } \\
\text { Mauser 2008; } \\
\text { Marzahn and } \\
\text { Ludwig 2009; } \\
\text { Wegmuller et al. } \\
2011\end{array}$ & No & $\begin{array}{l}\text { Non-destructive effects } \\
\text { on a soil surface; pos- } \\
\text { sibility of carrying out } \\
\text { measurements on the } \\
\text { same surface; registration } \\
\text { of large area; high data } \\
\text { accuracy; fast data acqui- } \\
\text { sition }\end{array}$ & $\begin{array}{l}\text { Limitation is the tendency } \\
\text { for roughness overesti- } \\
\text { mation }\end{array}$ \\
\hline
\end{tabular}

The pin and profile metres are simple tools, consisting of many parallelly arranged needles, lowered to the ground at regular, predetermined intervals. The height of the needles, relative to the level of the soil surface, is recorded electronically or photographically and later digitalized (Römkens et al. 1986, Wagner and Yiming 1991). The advantage of using such measuring equipment is its simplicity, easy workability and low cost, whereas the disadvantage is its destructive effect on the analysed soil surface and, therefore, no possibility of carrying out further measurements on the same surface (García Moreno et al. 2008b). According to García Moreno (2006), this tool is good for comparison of soil surface roughness in different management conditions in the field.

The roller chain was introduced by Saleh (1993), and in this method soil surface roughness is described by the degree of shortening of a roller chain laid on the soil surface. It is calculated as a ratio of the horizontal distance between chain ends placed on the soil surface to the full length of the chain. It is a very simple tool, inexpensive and giving reasonable results (Skidmore 1997). However, Thomsen et al. (2015) compared five different techniques to measure soil surface roughness expressed by random roughness (RR) and they claimed that nowadays the two contact methods mentioned above (the pin and profiles meter and the roller chain) have limited applicability, are time-consuming, impractical in the field and their precision as well as spatial resolution were much lower than non-contact methods.

Non-contact (non-invasive) techniques include a shadow analysis, a stereo-photography, a laser method and a synthetic-aperture radar (SAR). García Moreno et al. (2008a) proposed a shadow analysis technique based on the assumption that the shadows cast by the angle illumination are proportional to the size of the irregularities on the soil surface. The method based on the photo analysis is simpler and faster compared to the contact methods described above. The main disadvantage of the shadow analysis method is the high impact of soil colour and the content of organic matter and water in the soil on the accuracy of measurements (García Moreno et al. 2011). Therefore, the authors of this method emphasize that it is particularly effective for soils in central Spain, characterized by low moisture and organic matter content, and because of advantageous lighting conditions dominant in this region. 
The stereo-photography and the laser scanning techniques are characterized by a high resolution data created with the aid of three-dimensional models (3D) (Kamphorst et al. 2000). However, the laser technique is quite expensive due to the high cost of equipment and covers a rather small area at a time (Römkens and Wang 1987, Flanagan et al. 1995), whereas the calibration and configuration of the device is complicated (Bretar et al. 2013), processing is time-consuming and needs an extensive knowledge about image processing (Mirzaei et al. 2012). This method involves the formation of clouds of points with the spatial resolution from a few millimetres to a few centimetres, depending on the distance of the laser to the test object (Lichti and Jamtsho 2006). The laser scanners work in two modes, a single point in a time unit (point scanning) or a studied surface can be scanned at many points along the line per unit of time (scan lines). Therefore, laser (LIDAR) techniques require the use of expert software to process such obtained data (point clouds) (Thomsen et al. 2015). The results of the laser technique under laboratory conditions are more accurate than under field conditions during the day, since in the second case, the use of laser technology is limited due to interference with sunlight (Darboux and Huang 2003).

Zribi et al. (2000), Jester and Klik (2005) and Cierniewski et al. (2015) proposed various photogrammetry techniques to obtain data on the soil surface roughness both under laboratory and field conditions. This technique involves taking photos of a soil surface from different directions. Within these pictures, the reference targets have to be denoted on the soil surface in order to scale and register each created DEM. Optimal data acquisition conditions for outdoor measurements are cloudy weather because there are no shadows on the studied surface and changes in light conditions are limited. The altitude at which the pictures are taken should be within a range of 1 to $4 \mathrm{~m}$ above the sampled soil surface (Mirzaei et al. 2012) and for many applications, its area of about $1 \mathrm{~m}^{2}$ should be sufficient (Hansen et al. 1999, Kamphorst et al. 2000, Vidal Vázquez et al. 2006, Thomsen et al. 2015). Nouwakpo et al. (2010) conducted research at the plots of $2 \times 2 \mathrm{~m}$ and they suggested using photogrammetry technique for relatively small plots (area up to $3 \times 3 \mathrm{~m}$ ) since larger area can deform the geometric model. However, the plot of a given size must be large enough to obtain a representative elementary area (REA). This area is defined as the minimum area of the soil surface necessary to conduct reliable measurements. When the REA will be achieved a soil parameter becomes independent of the sample size (VandenBygaart and Protz 1998). One field should consist of several small plots whose number depends on the spatial variability of soil properties. According to Rieke-Zapp and Nearing (2005) and Linder (2006), for soil surface roughness measurements the image overlap of $65 \%$ is appropriate. Roughness indices are calculated from the acquired images. Gilliot et al. (2017) measured soil surface roughness on the basis of 13 images taken with a simple digital camera from various directions. Position and height accuracy of measurements (about 
$1.5 \mathrm{~mm}$ ) were determined using artificial, polystyrene models of soil surface, and the error of surface area estimation was less than $0.76 \%$. This method of measurement was applied on four cultivated fields where performed farming treatments caused different soil surface roughness levels. The roughness level in these fields was identified by means of roughness indices calculated from the images with an accuracy of $96 \%$.

Aguilar et al. (2009) compared photogrammetry and the laser scanning technique in terms of data acquisition, accuracy, resolution and indices computing capability of soil surface roughness. The research was based on generated DEMs for smooth and rough soil surfaces within the plot of $0.2 \mathrm{~m}^{2}$ located on two agricultural fields. The authors noted that both techniques create DEMs with very high resolution (about 1 and $0.4 \mathrm{~mm}$ for photogrammetric and laser scanner technique, respectively) and accuracy (standard deviations about 0.467 and $0.121 \mathrm{~mm}$ for photogrammetric and laser scanner technique, respectively). However, the both techniques have worse performance on rougher soil surfaces. The next similarities between both techniques are time of DEM's development (less than 2 hours) and a price of used devices, which were not too expensive. However, they claimed that the laser scanning technique can register a more detailed soil surface roughness model than the photogrammetric technique, whereas the digital photogrammetry allows data acquisition in a faster way.

Another non-contact sensor which can be used to assess soil surface roughness is a radar, due to the strong impact of soil surface roughness on the backscattered signal. However, in addition to soil surface roughness, its orientation also influences the backscattered signal (Wegmuller et al. 2011). The advantage of this technique is registration of larger areas, not limited to plots (Santanello et al. 2007, Loew and Mauser 2008). Marzahn and Ludwig (2009) tested multi temporal polarimetric synthetic-aperture radar (PolSAR) data to describe soil surface roughness and compared this technique with a photogrammetry method. They used microwave data in hydrological modelling. The test site had a size of $3 \times 8 \mathrm{~km}^{2}$ and was characterized by smooth topography and it was used for agricultural production. Soil surface roughness was measured by microwave backscatter recording imagery in X-, C- and L-band, during 11 E-SAR flights on a weekly basis. The authors consider this technique as very promising, because the results were sufficiently accurate $(\mathrm{RMSE}=0.1)$. However, they noted that presence of vegetation lead to overestimation of roughness and is not suitable for an operational use. Such an area covered partially with vegetation can be masked out during data processing and an applied operation would allow to slightly increase the roughness assessment accuracy. However, in the future it requires some enhancement, e.g. by solving the problem of mismatch between adjacent pixels caused by strong height and illumination differences.

Depending on the accepted measuring method of soil surface roughness, the spatial scale of the analysed surface and the amount of acquired data, vari- 
ous coefficients can be used to quantify soil surface roughness (García Moreno et al. 2008b). Martinez-Agirre et al. (2016), similarly to Smith (2014), divided these coefficients into four groups and in the first group there are parameters measuring the vertical dimension of soil surface roughness or the magnitude of the elevation variations of the points on the soil surface (vertical parameters). In the second group there are parameters measuring the horizontal dimension of soil surface roughness or the relation between the height of a point and that of its neighbours (horizontal parameters). In the next group there are parameters combining both dimensions (combined parameters). The last are parameters based on the fractal theory, which measure self-affinity between height variations at different spatial scales (fractal parameters). There are many statistical and geostatistical indices which have been proposed and tested for their ability to describe soil surface roughness (Allmaras et al. 1966, Linden and Van Doren 1986, Hansen et al. 1999). Random roughness (RR) is the most commonly used index in the studies described in literature. This index determines the standard deviation of heights to a reference plane and is transformed to natural logarithms. Besides, it is calculated after eliminating oriented roughness, determined by tillage tools from the analysed data (Allmaras et al. 1966). Currence and Lovely (1970) removed logarithmic transformation and calculated only the standard deviation of heights. After that this index was more sensitive and then used by most authors (Bertuzzi et al. 1990, Hansen et al. 1999, Kamphorst et al. 2000). However, the researchers noted some inaccuracies as regards using this parameter, because two the same hypothetical soil surfaces having the same roughness may have other RR values resulting from different field topographies (Merrill et al. 2001).

Two another indices for describing soil surface roughness are, the Height Standard Deviation (HSD) expressing a shape of soil surface within its delineated basic DEM unit (Marzahn et al. 2012) and $\mathrm{T}_{3 \mathrm{D}}$ expressing the ratio of the actual value of the DEM unit to a flat horizontal surface (Taconet and Ciarletti 2007). Soil surface roughness may also be described by the Root Mean Square (RMS) index (Allmaras et al. 1966) which was used in many studies (Malinverno 1990, Gallant et al. 1994, Vidal Vázquez et al. 2005). The index allows to evaluate the root mean square variation of elevation values at increasing lag distances (Vidal Vázquez et al. 2005). Vidal Vázquez et al. (2006) claimed that variational techniques, which include the RMS index, more precisely describe soil surface roughness in comparison to non-variational methods, including e.g. tortuosity or box counting. They obtained results with the respective coefficient of determination in the range of $0.972-1.000$. García Moreno et al. (2008b) analysed soil surface roughness created by three different types of tillage tools on three different soils. To describe soil surface roughness, they used the Standard Deviation (SD) parameter, which calculate values between all the data points within an area of about $1 \mathrm{~m}^{2}$. They also used the Coefficient 
of Variation (CV) representing the standard deviation based on the average value. The authors selected these parameters because they have more global representation compared to the RR and RMSH indexes. The authors obtained very similar results using both indices with the correlation of $99.9 \%$. Linden and Van Doren (1986) proposed two indices accounting for the spatial scale, based on the first order semivariogram, i.e. elevation difference measure, limiting elevation difference (LD) and limiting slope (LS). They are based on the average relief (elevation diversity) and the slope of clods occurring on a soil surface. The LD and LS indices describe the vertical component and also the interval length scale within soil surface roughness, respectively. Both indices are strongly related to the configuration of soil surface roughness and sensitive to diversity of soil roughness.

The mean upslope depression index (MUD) was developed by Hansen et al. (1999) to predict soil surface depression storage capacity. This index is based on the elevation differences between a reference point and another point placed on a line segment but above the reference point. Within each line, the calculations are conducted, taking into account a new reference point. The authors recommended segment length of $30 \mathrm{~cm}$. Martinez-Agirre et al. (2016) evaluated and selected the soil surface parameters, among 21 roughness parameters (divided into 4 groups), which best characterized soil surface roughness caused by tillage practices. The authors indicated LD and MUD, as the best parameters for differentiating various soil surface roughness caused by different tillage practices. However, the most sensitive parameters to rainfall action were LS and two fractal parameters: the crossover lengths $1_{\text {SMV }}$ (fitted to the first stretch of the semivariogram and the intercept of the linear trend) and $1_{\text {RMSH }}$ (crossover length). The researchers noted that the RR index is better for gentle sloping surfaces, whereas the MUD index better suits for steeper slopes. All the vertical parameters or the combined parameters, e.g. the standard deviation of heights or MUD, were highly correlated with each other, so the recommendation was to select the simplest parameters, which are mentioned above. The authors also presented the parameters which showed low correlation with the rest, e.g. $1_{\mathrm{SMV}}$ and LS.

\section{CONCLUSIONS}

1. Each tillage treatment creates a specified shape on the soil surface called soil surface roughness. A size of soil surface roughness and its stability depends on farming practices, weather conditions occurring during and after tillage treatments and soil properties. The presence of clay, organic carbon, iron oxide, calcium carbonate and moisture in soil promote creating larger and more stable surface roughness. 
2. Monitoring and systematically collected information about soil surface roughness is very important, because it plays a key role in agriculture, soil science, hydrology and remote sensing. Deepening the knowledge on the quantitative characterization of soil surface roughness formed by tillage tools can be used in the issues described above. The knowledge of soil surface roughness could allow to predict soil erosion intensity, determine amount and speed of flow surface and infiltration, predict the amount of water stored in the soil, thereby, it increases development of fauna and flora and improves the structure of soil and its biological quality. Furthermore, knowledge of quantitative soil surface roughness will allow more accuracy of interpretation of the soil properties using remote sensing techniques. The problem of disruptions of reflectance spectra caused by soil surface roughness is well known but is still not solved. The situation is similar to the issue of imaging spectroscopy data, which are used for prediction of quantitative surface soil properties.

3. In order to solve the above-mentioned issues, there is the necessity for a quantitative description of soil surface roughness. So far, many techniques for measuring and indices for estimation of soil surface roughness were developed and in this paper only some of them were presented. Each of the method or index have some advantages such as ease of use, low cost or high resolution of registered data. But these techniques have also some disadvantages such as a destructive effect on analysed soil surface and difficult workability or processing requirements. However, from various techniques, the authors recommend remote sensing methods which are non-contact, fast and can provide detailed data from large areas for estimation of soil surface roughness. Among the remote sensing sensors, SAR is very promising, since it can work in cloudy weather conditions and allow to register larger area compared to other detectors. The laser technique is quite expensive due to the high cost of equipment and covers a rather small area at a time. The calibration and configuration of the device is complicated, data processing is time-consuming and it requires extensive knowledge about image processing. Taking all this into account, the photogrammetry technique is better than laser scanning for registering soil surface roughness, because it is a faster technique. It also registers data with high accuracy, it is important because soil surface roughness may differ even within one field but these changes can be very subtle. A camera for stereo-photography is easy to use in the field, the image processing is simplified and software to process is absolutely clear (comprehensible to the user). However, when using this technique, there are some aspects that should be borne in mind, i.e. the altitude at which photographs are taken, the size of a plot in photos, reference target placed on registered soil surface. Also, the area of each photo has to partially coincide with the area of the photo taken from the neighbouring direction, creating a stereoscopic photo of analysed plots. Additionally, a photo of a few plots within one field should be taken. Further development of photogrammetric 
methods is associated with the possibility of using unmanned aerial vehicles (UAV) to carry the camera. The use of such a platform will allow even faster acquisition of variable resolution data depending on the altitude at which the images will be taken.

\section{ACKNOWLEDGEMENT}

This paper was supported by the National Science Centre, Poland (number of project 2016/21/N/ST10/00308).

\section{REFERENCES}

[1] Álvarez-Mozos, J., Campo, M.T., Gimenez, R., Casali, J., Leibar, U., 2011. Implications of scale, slope, tillage operation and direction in the estimation of surface depression storage. Soil and Tillage Research, 111(2): 142-153, DOI: 10.1016/j.still.2010.09.004.

[2] Abban, B.K.B., Papanicolaou, A.N.T., Giannopoulos, C.P., Dermisis, D.C., Wacha, K.M., Wilson, C.G., Elhakeem, M., 2017. Quantifying the changes of soil surface microroughness due to rainfall-induced erosion on a smooth surface. Nonlinear Processes in Geophysics, 24: 569-579, DOI: 10.5194/npg-2016-76.

[3] Aguilar, M.A., Aguilar, F.J., Negreiros, J., 2009. Off-the-shelf laser scanning and closerange digital photogrammetry for measuring agricultural soils microrelief. Biosystems Engineering, 103: 504-517, DOI: 10.1016/j.biosystemseng.2009.02.010.

[4] Allmaras, R.R., Burwell, R., Larson, W.E., Holt, R.F., 1966. Total porosity and random roughness of the interrow zone as influence by tillage. USDA Conservation Research Report 7.

[5] Amoah, J.K.O., Amatya, D.M., Nnaji, S., 2013. Quantifying watershed surface depression storage: determination and application in a hydrologic model. Hydrological Processes, 27(17): 2401-2413, DOI: 10.1002/hyp.9364.

[6] Arika, C.L., Gregory, J.M., Borrelli, J., Zartman, R.E., 1986. A ridge- and clod-wind erosion model. ASAE Paper No. 86-2531. ASAE, St. Joseph, MI.

[7] Arrouays, D., Grundy, M.G., Hartemink, A.E., Hempel, J.W., Heuvelink, G.B., Hong, S.Y., Zhang, G.L., 2014. Chapter three-global soil map: Toward a fine-resolution global grid of soil properties. Advances in Agronomy, 125: 93-134, DOI: 10.1016/B978-0-12-8001370.00003-0.

[8] Baghdadi, N., Cerdan, O., Zribi, M., Auzet, A.-V., Darboux, F., El Hajj, M., Kheir, R., 2008. Operational performance of current synthetic aperture radar sensors in mapping soil surface characteristics in agricultural environments: Application to hydrological and erosion modelling. Hydrological Processes, 22: 9-20, DOI: 10.1002/hyp.6609.

[9] Barthès, B.G., Kouakoua, E., Larré-Larrouy, M.C., Razafimbelo, T.M., de Luca, E.F., Azontonde, A., Neves, C.S.V.J., de Freitas, P.L., Feller, C.L., 2008. Texture and sesquioxide effects on water-stable aggregates and organic matter in some tropical soils. Geoderma, 143: $14-25$.

[10] Bayer, A., Bachmann, M., Müller, A., Kaufmann, H., 2012. A comparison of feature-based MLR and PLS regression techniques for the prediction of three soil constituents in a degraded South African ecosystem. Applied and Environmental Soil Science, 2012, DOI: $10.1155 / 2012 / 971252$. 
[11] Ben-Dor, E., Banin, A., 1995. Near-infrared analysis as a rapid method to simultaneously evaluate several soil properties. Soil Science Society of America Journal, 59(2): 364-372, 10.2136/sssaj1995.03615995005900020014x.

[12] Ben-Dor, E., Irons, J.R., Epema, G.F., 1999. Soil reflectance. In: A.N. Rencz (ed.), Manual of Remote Sensing: Remote Sensing for the Earth Sciences, $3^{\text {rd }}$ ed., New York, Wiley \& Sons, pp. 111-173.

[13] Ben-Dor, E., Goldshleger, Y., Benyamini, M.A., Blumberg, D.G., 2003. The spectral reflectance properties of soil structural crusts in the 1.2 to $2.5 \mu \mathrm{m}$ spectral region. Soil Science Society of America Journal, 67: 289-299.

[14] Ben-Dor, E., Chabrillat, S., Demattê, J.A.M., Taylor, G.R., Hill, J., Whiting, M.L., Sommer, S., 2009. Using imaging spectroscopy to study soil properties. Remote Sensing of Environment, 113: 38-55, DOI: 10.1016/j.rse.2008.09.019.

[15] Bertuzzi, P., Rauws, G., Courault, D., 1990. Testing roughness indices to estimate soil surface roughness changes due to simulated rainfall. Soil and Tillage Research, 17(1-2): 87-99, DOI: 10.1016/0167-1987(90)90008-2.

[16] Bielders, C.L., Baveye, P., Wilding, L.P., Drees, L.R., Valentin, C., 1996. Tillage-induced spatial distribution of surface crusts on a sandy Paleustulf from Togo. Soil Science Society America Journal, 60(3): 843-855.

[17] Bretar, F., Arab-Sedze, M., Champion, J., Pierrot-Deseilligny, M., Heggy, E., Jacquemoud, S., 2013. An advanced photogrammetric method to measure surface roughness: Application to volcanic terrains in the Piton de la Fournaise, Reunion Island. Remote Sensing of Environment, 135: 1-11, DOI: 10.1016/j.rse.2013.03.026.

[18] Bronick, C.J., Lal, R., 2005. Soil structure and management: A review. Geoderma, 124: 3-22, DOI: 10.1016/j.geoderma.2004.03.005.

[19] Brunet, D., Barthès, B.G., Chotte, J.L., Feller, C., 2007. Determination of carbon and nitrogen contents in alfisols, oxisols and ultisols from Africa and Brazil using NIRS analysis: Effects of sample grinding and set heterogeneity. Geoderma, 139: 106-117, DOI: 10.1016/j. geoderma.2007.01.007.

[20] Cecillon, L., Cassagne, N., Czarnes, S., Gros, R., Brun, J.-J., 2008. Variable selection in near infrared spectra for the biological characterization of soil and earthworm casts. Soil Biology and Biochemistry, 40: 1975-1979.

[21] Cerdan, O., Souchère, V., Lecomte, V., Couturier, A., Le Bissonnais, Y., 2002. Incorporating soil surface crusting processes in an expert-based runoff model: sealing and transfer by runoff and erosion related to agricultural management. CATENA, 46: 189-205.

[22] Cierniewski, J., 1987. A model for soil surface roughness influence on the spectral response of bare soils in the visible and near infrared range. Remote Sensing of Environment, 23: 97-115.

[23] Cierniewski, J., 1999. Geometrical modeling of soil bidirectional reflectance in the optical domain, Bogucki Scientific Publishers, Poznań.

[24] Cierniewski, J., Gdala, T., Karnieli, A., 2004. A hemispherical-directional reflectance model as a tool for understanding image distinctions between cultivated and uncultivated bare surfaces. Remote Sensing of Environment, 90: 505-523, DOI: 10.1016/j.rse.2004.01.004.

[25] Cierniewski, J., Kuśnierek, K., 2010. Influence of several soil properties on soil surface reflectance. Quaestiones Geographicae, 29(1): 13-25.

[26] Cierniewski, J., Kaźmierowski, C., Królewicz, S., Piekarczyk, J., 2013. Effects of soil roughness on the optimal time of cultivated soils observation by satellites for the soils average diurnal albedo approximation. IEEE Journal of Selected Topics in Applied Earth Observations and Remote Sensing, 6(3): 1194-1198, DOI: 10.1109/JSTARS.2012.2234440.

[27] Cierniewski, J., Karnieli, A., Kazmierowski, C., Krolewicz, S., Piekarczyk, J., Lewinska, K., Goldberg, A., Wesolowski, R., Orzechowski, M., 2015. Effects of soil surface irregularities on the diurnal variation of soil broadband blue-sky albedo. IEEE Journal of Selected Topics in Applied Earth Observations and Remote Sensing, 8(2): 493-502, DOI: 10.1109/ JSTARS.2014.2330691. 
[28] Croft, H., Anderson, K., Kuhn, N.J., 2012. Reflectance anisotropy for measuring soil surface roughness of multiple soil types. CATENA, 93: 87-96, 10.1016/j.catena.2012.01.007.

[29] Cruse, R.M., Linden, D.R., Radke, J.K., Larson, W.E., Larntz, K., 1980. A model to predict tillage effects on soil temperature. Soil Science Society of America Journal, 44(2): 378-383, DOI: $10.2136 /$ sssaj1980.03615995004400020034x.

[30] Currence, H.D., 1969. Development of a method for measuring and describing soil surface roughness. Retrospective Theses and Dissertations, 3568.

[31] Currence, H.D., Lovely, W.D., 1970. Analysis of soil surface roughness. Transactions of the ASAE, 13(6): 710-714.

[32] Darboux, F., Davy, Ph., Gascuel-Odoux, C., Huang, C., 2002. Evolution of soil surface roughness and flowpath connectivity in overland flow experiments. CATENA, 46(2-3): 125-139, DOI: 10.1016/S0341-8162(01)00162-X.

[33] Darboux F., Huang C.-h., 2003. An instantaneous-profile laser scanner to measure soil surface microtopography. Soil Science Society of America Journal, 67(1): 92-99, DOI: 10.2136/ sssaj2003.9200.

[34] Daughtry, C.S.T., Doraiswamy, P.C., Hunt Jr., E.R., Stern, A.J., McMurtrey III, J.E., Prueger, J.H., 2006. Remote sensing of crop residue cover and soil tillage intensity. Soil and Tillage Research, 91: 101-108.

[35] Duiker, S.W., Rhoton, F.E., Torrent, J., Smeck, N.E., Lal, R., 2003. Iron (hydr)oxide crystallinity effects on soil aggregation. Soil Science Society of America Journal, 67: 606-611, DOI: $10.2136 /$ sssaj2003.0606.

[36] FAO, 2011. The State of Food Insecurity in the World 2011: How Does International Price Volatility Affect Domestic Economies and Food Security. Food and Agriculture Organization of the United Nations, Rome.

[37] Flanagan, D.C., Huang, C., Norton, L.D., Parker, S.C., 1995. Laser scanner for erosion plot measurements. Transactions of the ASAE, 38: 703-710.

[38] Foley, J.A., Defries, R., Asner, G., Barford, C., Bonan, G., Carpenter, S., Chapin III, F.S., Coe, M., Daily, G., Gibbs, H., Helkowski, J.H., Holloway, T., Howard, E.A., Kucharik, C., Monfreda, C., Patz, J., Prentice, I., Ramankutty, N., Snyder, P.K., 2005. Global consequences of land use. Science, 309: 570-574 (New York), DOI: 10.1126/science.1111772.

[39] Foley, J.A., Ramankutty, N., Brauman, K.A., Cassidy, E.S., Gerber, J.S., Johnston, M., Mueller, N.D., O’Connell, C., Ray, D.K., West, P.C., Balzer, C., Bennett, E.M., Carpenter, S.R., Hill, J., Monfreda, C., Polasky, S., Rockström, J., Sheehan, J., Siebert, S., Tilman, D., Zaks, D.P.M., 2011. Solutions for a cultivated planet. Nature, 478: 337-42, DOI: 10.1038/nature10452.

[40] Fryrear, D.W., 1984. Soil ridge-clods and wind erosion. Transactions of the ASAE, 27(2): 445-448, DOI: 10.13031/2013.32808.

[41] Gallant, J.C., Moore, I.D., Hutchinson, M.F., Gessler, P., 1994. Estimating fractal dimension of profiles: A comparison of methods. Mathematical Geology, 26(4): 455-481.

[42] García Moreno, R., 2006. Development of a methodology for the measurement of soil roughness (in Spanish). Ph. D. Dissertation, Polytechnic University of Madrid (UPM), p. 120.

[43] García Moreno, R., Requejo, A.S., Alonso, A.M.T., Barrington, S., Diaz, M.C., 2008a. Shadow analysis: A method for measuring soil surface roughness. Geoderma, 146: 201-208.

[44] García Moreno, R., Álvarez, M.C.D., Alonso A.M.T., Barrington S., Requejo, A.S., 2008 b. Tillage and soil type effects on soil surface roughness at semiarid climatic conditions. Soil and Tillage Research, 98: 35-44.

[45] García Moreno, R., Requejo, A.S., Altisent, J.M.D., Álvarez, M.C.D., 2011. Significance of soil erosion on soil surface roughness decay after tillage operations. Soil and Tillage Research, 117: 49-54, DOI: 10.1016/j.still.2011.08.006.

[46] Génermont, S., Cellier, P., 1997. A mechanistic model for estimating ammonia volatilization from slurry applied to bare soil. Agricultural and Forest Meteorology, 88(1-4): 145-167, DOI: 10.1016/S0168-1923(97)00044-0. 
[47] Ghidey, F., Alberts, E.E., 1998. Runoff and soil losses as affected by corn and soybean tillage systems. Journal of Soil and Water Conservation, 53: 64-70.

[48] Gilliot, J.M., Vaudour, E., Michelin, J., 2017. Soil surface roughness measurement: A new fully automatic photogrammetric approach applied to agricultural bare fields. Computers and Electronics in Agriculture, 134: 63-78, DOI: 10.1016/j.compag.2017.01.010.

[49] Ginting, D., Moncrief, J.F., Gupta, S.C., Evans, S.D., 1998. Corn yield, runoff, and sediment losses from manure and tillage systems. Journal of Environmental Quality, 27: 1396-1402.

[50] Grunwald, S., Thompson, J.A., Boettinger, J.L., 2011. Digital soil mapping and modeling at continental scales: Finding solutions for global issues. Soil Sciences Society of America Journal, 75: 1201-1213.

[51] Guanter, L., Kaufmann, H., Segl, K., Förster, S., Rogaß, C., Chabrillat, S., Küster, T., Hollstein, A., Rossner, G., Chlebek, C., et al., 2015. The EnMAP spaceborne imaging spectroscopy mission for Earth observation. Remote Sensing, 7: 8830-8857, DOI: 10.3390/rs70708830.

[52] Hansen, B., Schjönning, P., Sibbesen, E., 1999. Roughness indices for estimation of depression storage capacity of tilled soil surfaces. Soil and Tillage Research, 52(1-2): 103-111, DOI: 10.1016/S0167-1987(99)00061-6.

[53] Hauer, G., Klik, A., Jester, W., Truman, C.C., 2001. Field Investigations of Rainfall Impact on Soil Erosion and Soil Surface Roughness. Soil Erosion Research for the $21^{\text {st }}$ Century, Proc. Int. Symp. (3-5 January, Honolulu, USA). Eds. J.C. Ascough II, D.C. Flanagan. St. Joseph, MI: ASAE: 467-470, DOI: 10.13031/2013.4578.

[54] Herodowicz, K., 2017. Influence of the distance between a reflectance sensor and soil samples with different roughness. Polish Journal of Soil Science, XLIX(2): 133-147, DOI: 10.17951/pjss/2016.49.2.133.

[55] Huang, C., Bradford, J.M., 1992. Applications of a laser scanner to quantify soil microtopography. Soil Science Society of America Journal, 56(1): 14-21, DOI: 10.2136/sssaj1992.03615995005600010002x.

[56] Iziomon, M.G., Mayer, H., 2002. On the variability and modelling of surface albedo and long-wave radiation components. Agricultural and Forest Meteorology, 111: 141-152, DOI: 10.1016/S0168-1923(02)00013-8.

[57] Jester, W., Klik, A., 2005. Soil surface roughness measurement methods, applicability, and surface representation. CATENA, 64: 174-192, DOI: 10.1016/j.catena.2005.08.005.

[58] Jones, C., Kiniry, J., 1986. CERES-Maize, A Simulation Model of Maize Growth and Development. College Station, Texas A\&M University Press, College Station.

[59] Kamphorst, E.C., Jetten, V., Guérif, J., Pitkänen, J., Iversen, B.V., Douglas, J.T., Paz, A., 2000. How to predict maximum water storage in depressions from soil roughness measurements. Soil Science Society of America Journal, 64(5): 1749-1758.

[60] Korucu, T., Selvi, K.C., Ince, I., 2016. Effect of different subsoiling applications on soil surface roughness. International symposium ISB-INMA THE Agricultural and mechanical engineering, Bucharest, 27-29 October.

[61] Larney, F.J., Bullock, M.S., McGinn, S.M., Fryrear, D.W., 1995. Quantifying wind erosion on summer fallow in southern Alberta. Journal of Soil and Water Conservation, 50(1): 91-95.

[62] Larney, F.J., Cessna, A.J., Bullock, M.S., 1999. Herbicide transport on wind-eroded sediment. Journal of Environmental Quality, 28(5): 1412-1421, DOI: 10.2134/ jeq1999.00472425002800050004x.

[63] Lichti, D.D., Jamtsho, S., 2006. Angular resolution of terrestrial laser scanners. The Photogrammetric Record, 21(114): 141-160, DOI: 10.1111/j.1477-9730.2006.00367.x.

[64] Linden, D.R., Van Doren, Jr., 1986. Parameters for characterizing tillage-induced soil surface roughness. Soil Science Society of America Journal, 50: 1560-1565, DOI: 10.2136/ sssaj1986.03615995005000060035x.

[65] Linder, W., 2006. Digital photogrammetry, a practical course, Springer, Berlin-HeidelbergNew York, p. 214, DOI: 10.1007/3-540-29153-9. 
[66] Lobb, D.A., Huffman, E., Reicosky, D.C., 2007. Importance of information on tillage practices in the modelling of environmental processes and in the use of environmental indicators. Journal of Environmental Management, 82: 377-387, DOI: 10.1016/j.jenvman.2006.04.019.

[67] Loew, A., Mauser, W., 2008. Inverse modeling of soil characteristics from surface soil moisture observations: potential and limitations. Hydrology and Earth System Sciences Discussions, 5: 95-145, DOI: 10.5194/hessd-5-95-2008.

[68] Magunda, M.K., Larson, W.E., Linden, D.R., Nacer, E.A., 1997. Changes in microrelief and their effects on infiltration and erosion during simulated rainfall. Soil Technology, 10(1): 57-67, DOI: 10.1016/0933-3630(95)00039-9.

[69] Malinverno, A., 1990. A simple method to estimate the fractal dimension of a self-affine series. Geophysical Research Letters, 17(11): 1953-1956, DOI: 10.1029/GL017i011p01953.

[70] Martinez-Agirre, A., Álvarez-Mozos, J., Giménez, R., 2016. Evaluation of surface roughness parameters in agricultural soils with different tillage conditions using a laser profile meter. Soil and Tillage Research, 161: 19-30, DOI: 10.1016/j.still.2016.02.013.

[71] Marzahn, P., Ludwig, R., 2009. On the derivation of soil surface roughness from multi parametric PolSAR data and its potential for hydrological modeling. Hydrology and Earth System Sciences, 13(3): 381-394, DOI: 10.5194/hessd-5-3383-2008.

[72] Marzahn, P., Rieke-Zapp, D., Ludwig, R., 2012. Assessment of soil surface roughness statistics for microwave remote sensing applications using a simple photogrammetric acquisition system. ISPRS Journal of Photogrammetry and Remote Sensing, 72: 80-89, DOI: 10.1016/j. isprsjprs.2012.06.005.

[73] Matthias, A.D., Fimbres, A., Sano, E.E., Post, D.F., Accioly, L., Batchily, A.K., Ferreira, L.G., 2000. Surface roughness effects on soil albedo. Soil Science Society of America Journal, 64(3): 1035-1041, DOI: 10.2136/sssaj2000.6431035x.

[74] Merrill, S.D., Huang, C., Zobeck, T.M., Tanaka, D.L., 2001. Use of the chain set for scale-sensitive and erosion relevant measurement of soil surface roughness. In: D.E. Stott, R.H. Mohtar, G.C. Steinhardt, (eds.), Sustaining the Global Farm. Selected papers from the $10^{\text {th }}$ International Soil Conservation Organization Meeting held May 24-29, 1999 at Purdue University and the USDA-ARS, National Soil Erosion Research, 594-600.

[75] Mikhajlova, N.A., Orlov, D.S., 1986. Optical properties of soils and soil components (in Russian). Moskva, Russia, Nauka, 35-38.

[76] Mirzaei, M., Ruy, S., Ziarati, T., 2012. Monitoring of soil roughness caused by rainfall using stereo-photogrammetry. International Research Journal of Applied and Basic Sciences, 3(2): 322-338.

[77] Moldenhauer, W.C., 1970. Influence of rainfall energy on soil loss and infiltration rates: II. Effect of clod size distribution. Soil Science Society of America Journal, 34(2): 673-677 DOI: 10.2136/sssaj1970.03615995003400040037x.

[78] Moron, A., Cozzolino, D., 2003. Exploring the use of near infrared reflectance spectroscopy to study physical properties and microelements in soils. Journal of Near Infrared Spectroscopy, 154: 145-154.

[79] Murillo, J.M., Moreno, E., Girón, I.F., Oblitas, M.I., 2004. Conservation tillage: long term effect on soil and crops under rained conditions in south-west Spain (Western Andalusia). Spanish Journal Agricultural Research, 2(1): 35-43.

[80] Nanni, M.R., Demattê, J.A.M., 2006. Spectral reflectance methodology in comparison to traditional soil analysis. Soil Science Society of America Journal, 70(2): 393-407, DOI: 10.2136/sssaj2003.0285.

[81] Nouwakpo, S., Huang, Ch., Frankenberger, J., Bethel, J., 2010. A simplified close range photogrammetry method for soil erosion assessment. $2^{\text {nd }}$ Joint Federal Interagency Conference, Las Vegas, NV, 27 June-1 July.

[82] Oades, J.M., Waters, A.G., 1991. Aggregate hierarchy in soils. Australian Journal of Soil Research 29: 815-828, DOI: 10.1071/SR9910815. 
[83] Or, D., Smets, B.F., Wraith, J.M., Dechesne, A., Friedman, S.P., 2007. Physical constraints 30 affecting bacterial habitats and activity in unsaturated porous media - a review. Advances in Water Resources, 30: 1505-1527.

[84] Pardini, G., 2003. Fractal scaling of surface roughness in artificially weathered smectite-rich soil regoliths. Geoderma, 117(1-2): 157-167, DOI: 10.1016/S0016-7061(03)00164-2.

[85] Piekarczyk, J., Kazmierowski, C., Krolewicz, S., Cierniewski, J., 2016. Effects of soil surface roughness on soil reflectance measured in laboratory and outdoor conditions. IEEE Journal of Selected Topics in Applied Earth Observations and Remote Sensing, 9: 827-834, DOI: 10.1109/JSTARS.2015.2450775.

[86] Potter, K.N., Horton, R., Cruse, R.M., 1987. Soil surface roughness effects on radiation reflectance and soil heat flux. Soil Science Society of America Journal, 51 (4): 855-860.

[87] Potter, K.N., Zobeck, T.M., Hagen, L.J., 1990. A micro-relief index to estimate soil erodibility by wind. Transactions of the ASAE, 33(1): 151-155, DOI: 10.13031/2013.31309.

[88] Power, A.G., 2010. Ecosystem services and agriculture: tradeoffs and synergies. Philosophical Transactions of the Royal Society B, 365: 2959-2971, DOI: 10.1098/rstb.2010.0143.

[89] Ramankutty, N., Foley, J.A., Norman, J., McSweeney, K., 2002. The global distribution of cultivable lands: current patterns and sensitivity to possible climate change. Global Ecology and Biogeography, 11(5): 377-392, DOI: 10.1046/j.1466-822x.2002.00294.x.

[90] Ramankutty, N., Evan, A.T., Monfreda, C., Foley, J.A., 2008. Farming the planet: 1. Geographic distribution of global agricultural lands in the year 2000. Global Biogeochemical Cycles, 22(1): GB1003, DOI: 10.1029/2007GB002952.

[91] Richter, N., Chabrillat, S., Kaufmann, H., Gfz, G.P., Sensing, S.R., 2005. Preliminary analysis for soil organic carbon determination from spectral reflectance in the frame of the EU project DeSurvey. The $1^{\text {st }}$ International Conference on Remote Sensing and Geoinformation Processing in the Assessment of Land Degradation and Desertification, Trier, September 7-9, Sierra 1-6.

[92] Richter, N., Jarmer, T., Chabrillat, S., Oyonarte, C., Hostert, P., Kaufmann, H., 2009. Free iron oxide determination in Mediterranean soils using diffuse reflectance spectroscopy. Soil Science Society of America Journal, 73(1): 72-81, DOI: 10.2136/sssaj2008.0025.

[93] Rieke-Zapp, D.H., Nearing, M.A., 2005. Digital close range photogrammetry for measurement of soil erosion. Photogrammetric Record, 20: 69-87, DOI: 10.1111/j.14779730.2005.00305.x.

[94] Röhrig, R., Langmaack, M., Schrader, S., Larink, O., 1998. Tillage systems and soil compaction - their impact on abundance and vertical distribution of Enchytraeidae. Soil and Tillage Research, 46(1-2): 117-127, DOI: 10.1016/S0167-1987(98)80113-X.

[95] Römkens, M.J.M., Wang, J. Y., 1986. Effect of tillage on surface roughness. Transactions of the ASAE, 29(2): 429-433, DOI: 10.13031/2013.30167.

[96] Römkens, M.J.M., Singarayar, S., Gantzer, C.J., 1986. An automated non contact surface profile meter. Soil and Tillage Research, 6(3): 193-202, DOI: 10.1016/0167-1987(86)90454-X.

[97] Römkens, M.J. M., Wang, J.Y., 1987. Soil roughness changes from rainfall. Transactions of the ASAE, 30(1): 101-107, DOI: 10.13031/2013.30409.

[98] Rosa, J.D., Cooper, M., Darboux, F., Medeiros, J.C., 2012. Soil roughness evolution in different tillage systems under simulated rainfall using a semivariogram-based index. Soil and Tillage Research, 124: 226-232, DOI: 10.1016/j.still.2012.06.001.

[99] Saleh, A., 1993. Soil roughness measurement: Chain method. Journal of Soil and Water Conservation, 48(6): 527-529.

[100] Santanello, J.A., Peters-Lidard, C.D., Garcia, M.E., Mocko, D.M., Tischler, M.A., Moran, M.S., Thoma, D.P., 2007. Using remotely-sensed estimates of soil moisture to infer soil texture and hydraulic properties across a semi-arid watershed. Remote Sensing of Environment, 110(1): 79-97, DOI: 10.1016/j.rse.2007.02.007.

[101] Skidmore, E.L., 1997. Comments on chain methods for measuring soil roughness. Soil Science Society of America Journal, 61(5): 1532-1533. 
[102] Smith, M., 2014. Roughness in the Earth Sciences Earth-Science Reviews, 136: 202-225, DOI: 10.1016/j.earscirev.2014.05.016.

[103] Steinberg, A., Chabrillat, S., Stevens, A., Segl, K., Foerster, S., 2016. Prediction of common surface soil properties based on Vis-NIR airborne and simulated EnMAP imaging spectroscopy data: Prediction accuracy and influence of spatial resolution. Remote Sensing, 8(7): 613, DOI: 10.3390/rs8070613.

[104] Stevens, A., van Wesemael, B., Bartholomeus, H., Rosillon, D., Tychon, B., Ben-Dor, E., 2008. Laboratory, field and airborne spectroscopy for monitoring organic carbon content in agricultural soils. Geoderma, 144: 395-404, DOI: 10.1016/j.geoderma.2007.12.009.

[105] Stevens, A., Udelhoven, T., Denis, A., Tychon, B., Lioy, R., Hoffmann, L., van Wesemael, B., 2010. Measuring soilorganic carbon in croplands at regional scale using airborne imaging spectroscopy. Geoderma, 158: 32-45.

[106] Sullivan, D.G., Shaw, J.N., Rickman, D., 2005. IKONOS imagery to estimate surface soil property variability in two Alabama physiographies. Soil Science Society of America Journal, 69: 1789-1798.

[107] Taconet, O., Ciarletti, V., 2007. Estimating soil roughness indices on a ridge-and-furrow surface using stereo photogrammetry. Soil and Tillage Research, 93: 64-76, DOI: 10.1016/j. still.2006.03.018.

[108] Thomsen, L.M., Baartman, J.E.M., Barneveld, R.J., Starkloff, T., Stolte, J., 2014. Soil surface roughness: comparing old and new measuring methods and application in a soil erosion model. SOIL, 1: 981-1012, DOI: 10.5194/soild-1-981-2014.

[109] Thomsen, L.M., Baartman, J.E.M., Barneveld, R.J., Starkloff, T., Stolte, J., 2015. Soil surface roughness: comparing old and new measuring methods and application in a soil erosion model. SOIL, 1: 399-410, DOI: 10.5194/soil-1-399-2015.

[110] VandenBygaart, A.J., Protz, R., 1998. The representative elementary area (REA) in studies of quantitative soil micromorphology. Geoderma, 89(1999): 333-346.

[111] Van der Meer, F., 1995. Spectral reflectance of carbonate mineral mixtures and bidirectional reflectance theory: Quantitative analysis techniques for application in remote sensing. Remote Sensing Reviews, 13(1-2): 67-94, DOI: 10.1080/02757259509532297.

[112] Vannier, E., Gademer, A., Ciarletti, V., 2006. A new approach for roughness analysis of soil surfaces. 14 $4^{\text {th }}$ European Signal Processing Conference (EUSIPCO), Florence, Italy, 4-8 September.

[113] Vaudour, E., Bel, L., Gilliot, J.M., Coquet, Y., Hadjar, D., Cambier, P., Michelin, J., Houot, S., 2013. Potential of SPOT multispectral satellite images for mapping topsoil organic carbon content over peri-urban croplands. Soil Science Society of America Journal, 77(6): 2122-2139, DOI: 10.2136/sssaj2013.02.0062.

[114] Verhoest, N.E.C., Lievens, H., Wagner, W., Álvarez-Mozos, J., Moran, M.S., Mattia, F., 2008. On the soil roughness parameterization problem in soil moisture retrieval of bare surfaces from synthetic aperture radar. Sensors, 8(7): 4213-4248.

[115] Vermang, J., Norton, L.D., Baetens, J.M., Huang, C., Cornelis, W.M., Gabriels, D., 2013. Quantification of soil surface roughness evolution under simulated rainfall. American Society of Agricultural Engineers, 56: 505-514, DOI: 10.13031/2013.42670.

[116] Vidal Vázquez, E., González, P.A., Miranda, V.J.G., 2005. Characterizing anisotropy and heterogeneity of soil surface microtopography using fractal models. Ecological Modelling, 182(3-4): 337-353, DOI: 10.1016/j.ecolmodel.2004.04.012.

[117] Vidal Vázquez, E., Miranda, V.J.G., Alves, M.C., González, P.A., 2006. Effect of tillage on fractal indices describing soil surface microrelief of a Brazilian Alfisol. Geoderma, 134: 428-439, DOI: 10.1016/j.geoderma.2006.03.012.

[118] Vidal Vázquez, E., Miranda, V.J.G., González, P.A., 2007. Describing soil surface microrelief by crossover length and fractal dimension. Nonlinear Processes in Geophysics, 14(3): 223-235, DOI: 10.5194/npg-14-223-2007. 
[119] Viscarra Rossel, R.A., McGlynn, R.N., McBratney, A.B., 2006. Determining the composition of mineral-organic mixes using $U V-v i s-N I R$ diffuse reflectance spectroscopy. Geoderma, 137: 70-82.

[120] Wagner, L.E., Yiming, Y., 1991. Digitization of profile meter photographs. Transactions of the ASAE, 34(2): 412-416.

[121] Wegmuller, U., Santoro, M., Mattia, F., Balenzano, A., Satalino, G., Marzahn, P., Ludwig, R., Floury, N., 2011. Progress in the understanding of narrow directional microwave scattering of agricultural fields. Remote Sensing of Environment, 115(10): 2423-2433, DOI: 10.1016/j.rse.2011.04.026.

[122] Wischmeier, W.H., Smith, D.D., 1978. Predicting Rainfall Erosion Losses. A Guide to Conservation Planning. Agriculture Handbook. Department of Agriculture Science and Education Administration, Washington, D.C., USA.

[123] Young, I.M., Crawford, J.W., Rappoldt, C., 2001. New methods and models for characterising structural heterogeneity of soil. Soil and Tillage Research, 61(1-2): 33-45, DOI: 10.1016/S0167-1987(01)00188-X.

[124] Zheng, B., Campbell, J.B., Serbin, G., Galbraith, J.M., 2014. Remote sensing of crop residue and tillage practices: Present capabilities and future prospects. Soil and Tillage Research, 138: 26-34, DOI: 10.1016/j.still.2013.12.009.

[125] Zhixiong, L., Nan, C., Perdok, U.D., Hoogmoed, W.B., 2005. Characterisation of soil profile roughness. Biosystems Engineering, 91(3): 369-377, DOI: 10.1016/j.biosystemseng.2005.04.004.

[126] Zribi, M., Ciarletti, V., Taconet, O., Paillé, J., Boissard, P., 2000. Characterisation of the soil structure and microwave backscattering based on numerical three-dimensional surface representation: Analysis with a fractional Brownian model. Remote Sensing of Environment, 72: 159-169, DOI: 10.1016/S0034-4257(99)00097-8. 